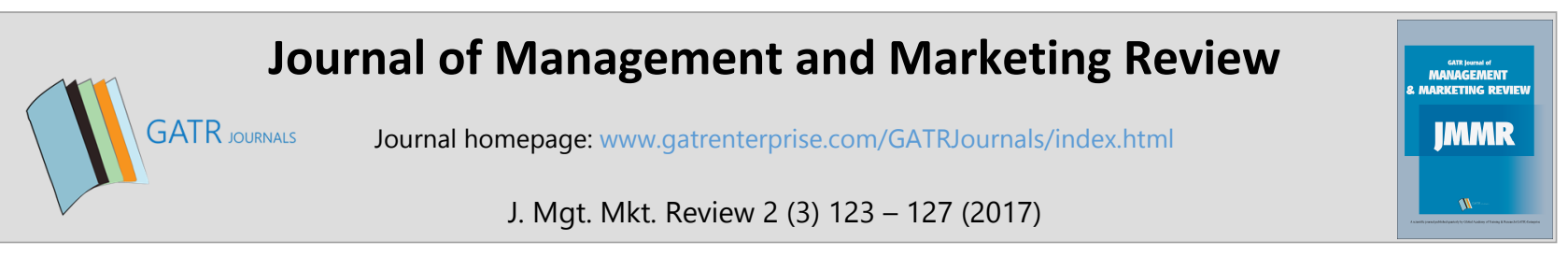

\title{
Power Distance as A National Culture Observed in Organizational Scope
}

\author{
Arief Noviarakhman Zagladi* \\ Pancasetia School of Economics, Jl. Ahmad Yani Km 5,5, 70248, Banjarmasin, Indonesia
}

\begin{abstract}
Objective - Cultural factors have significant roles in creating behavior in an organization. This research claims that national culture like power distance that is usually measured in a national scope actually can have a better result when it is measured in the organizational scope. The goal of this research is to find out the level of power distance among private lecturers in Banjarmasin, Indonesia, and compare it to Hofstede's power distance for the whole country.

Methodology/Technique - This research uses explanatory research that tries to understand the degree of power distance among private university lecturers in Banjarmasin. The populations used were all lecturers in private colleges in Banjarmasin City. The samples used were 86 lecturers who have become a lecturer for at least 2 years. The analysis is done through a descriptive quantitative method measuring the level of power distance among lecturers in Banjarmasin and with confirmatory factor analysis (CFA) to understand which indicators that have the strongest influence in creating power distance culture among lecturers in Banjarmasin.

Findings - The results of the research show that power distance culture is low among the lecturers in Banjarmasin City, with indicator "The level of authority used by the leader" as the lowest factor. The result also finds that the indicator "subordinates Exclusion in decision-making" as the strongest indicator to form power distance culture.
\end{abstract}

Novelty - This research conducted in the context of Indonesia using primary data.

Type of Paper: Empirical

Keywords: National culture; Organizational culture; Power distance; Hofstede; Banjarmasin City.

JEL Classification: M50, M54.

\section{Introduction}

Organization can be translated as a group of people who interact with each other to achieve certain goals (McShane \& Glinow, 2008). A good understanding of how an organization works would help managers to manage their organizations effectively.

Among many things that interact in an organization, there is one factor that is hard to ignore, that is cultural factors. There have been a lot of researches showing that national culture has a strong influence on the organization (Adair, Okumura, \& Brett, 2001). Another opinion also confirms that national culture has an important role in shaping organizational behavior (Aldhuwaihi, 2013). Yoon (1996) also asserts that despite the fact that cultural values and social norms are essential for the society, its existence can also cause bias in the perception of the principles applied to the organization.

\footnotetext{
* Paper Info: Received: February 13, 2017

Accepted: July 10, 2017

* Corresponding author:

E-mail: a_zagladi@yahoo.com

Affiliation: Pancasetia School of Economics, Indonesia
} 
This study is trying to reveal the development of power distance culture on educational institution in Banjarmasin City, South Kalimantan. It is important to understand the development of power distance culture at educational institutions, as it is different from the previous researches, most of which are done at private companies.

\section{Literature Review}

Power distance culture is one of the national culture's element that serves to explain the difference in power between a subordinate with a boss ( $\mathrm{Wu}, 2006)$. Power distance as a national culture has been investigated by Hofstede and has been widely cited by other researchers around the world (Jones, 2007).

Power distance is a certain limit for a person to accept the existence of unequal distribution of power in society (McShane \& Glinow, 2008). Power distance is one of the dimensions used by Hofstede to measure a country's national culture. In the last three decades (1984-2001), Hofstede's cultural dimension has been used as a paradigm of research in the field of intercultural communication, cross-cultural psychology, and international management (Wu, 2006). According to Hofstede on its website: http://geert-hofstede.com /indonesia.html, Indonesia has a high power distance values, with a score of 78 in 2016. This score implies that most citizens of Indonesia are very defendant on the hierarchy and most of the tasks in an organization are performed by the management

Power distance is also translated as the limit of power imbalances which is accepted by the society as normal and is part of everyday life (Hellrieger \& John W. Slocum, 2009). Individuals who grow up in a culture that contain high power distance will always strive to bow to superiors and agree with their every action. Subordinates will generally carry out orders without asking questions and doing their work as ordered. Violating the orders from a superior person or doing anything without the knowledge of a superior person is regarded as a grave problem.

In other communities that have a low power distance culture, leaders and subordinates understand that they need each other. Things like formalities is regarded as something that slows the completion of the work, and sometimes it is okay to be violated by subordinates. Subordinates sometimes openly raise objections if the leader makes an order that is considered unsuitable.

Social science researchers began to doubt the accuracy of measuring the power distance culture in a nationwide scope. Jones (2007) collects opinions from experts who questioned the results of the Hofstede's cultural assessment, one of which is power distance culture. These opinions include the relevance, cultural homogeneity of society, state boundaries, and Hofstede's one-company-approach. By relevance, researches with survey techniques are considered not good enough to understand something as sensitive as culture in the national scope. From the side of the cultural homogeneity of society, Hofstede's research tends to ignore the fact that a country is made up of various ethnic groups with different sub cultures. In terms of state boundaries, most researchers believe that the State is no longer considered capable of being the scope of a culture, because global community has begun to blend into each other as a result of the rapidly increasing flow of transportation, information, and communication. Culture is better measured within the scope of the group or groups of people. In terms of one-company-approach, experts believe that a research which is conducted at one company only is considered incapable of representing a country as a whole.

McSweeney's (2000) opinion states that culture should not be measured nationally since today's culture is no longer confined by national boundaries. Research from Kwon (2012) shows that in the same country (China), he found that power distance index values vary in each community. Piller (2011) suggests that there are clear power distance cultural differences between the educated person and those who are not, between people who live in cities and those living in the villages, or between people with high incomes and those with low incomes. Therefore, researchers suggest that power distance culture should be measured with primary data on small and homogenized communities in order to obtain accurate results.

Most nowadays researchers measure power distance using other indicators than the one used by Hofstede. Beside the indicators from Dorfman and Howell (1988), researchers also measure power distance using power 
distance indicators by Robertson and Hoffman (2000), as in the research conducted by Wang and Nayir (2010). These actions were taken as a manifestation of a criticism to Hofstede (Dorfman \& Howell, 1988), that one of them is cultural homogeneity. The Hofstede's research assumes that most people live in a homogeneous country, while actually almost all countries nowadays are made up of various ethnic groups (Nasif, Al-Daeaj, Ebrahimi, \& Thibodeaux, 1991). Hofstede tends to overlook the importance of a small community, and variations which are influenced by the community (Dorfman \& Howell, 1988). Recent researches state that cultures should not be measured nationally since cultures today are no longer confined by national borders (McSweeney, 2000). Therefore, when you want to measure power distance cultures, researchers should measure it within the primary data, to in order to get accurate results.

\section{Methodology}

This research is a descriptive quantitative research which is aimed at seeing the level of power distance measured at college lecturers in the city of Banjarmasin, South Kalimantan, Indonesia. College lecturers are used as the population because this research wants to address Piller's (2011) opinion that people with higher education should have a different power distance culture than those with lower education.

Among all the college lecturers in the city of Banjarmasin, 582 lecturers lectured for more than 2 years. The number of the sample was taken using Slovin's formula with an error rate of $10 \%$ that creates 86 respondents. The samples were chosen using simple random sampling technique because the technique was considered the best one if the goal of the research is to generalize the results.

The measurement used to measure the power distance culture in this study was 5 indicators from Dorfman and Howell (1988), which aimed to determine the extent of the power gap between leaders and subordinates which is still considered reasonable. The first indicator is the level of subordinates involvement in decision making. This indicator measures the extent to which a leader is willing to involve his subordinates in the process of making decisions or strategic rules.

The second indicator is the level of the usage of authority of the leaders. This indicator measures the extent to which a leader would use his power to suppress his subordinates. In organizations with a high power distance culture, a leader can take advantage of his position to order his subordinates to do things outside the scope of work. In organizations with low power distance cultures, this kind of behavior will be objected by the subordinates.

The third indicator is the leader's acceptance of suggestions and opinions from the subordinates. This indicator measures the extent to which a leader is willing to listen to suggestions and opinions from subordinates. The fourth indicator is a subordinate attitude toward a leader's decision. This indicator measures the extent to which subordinate believes that everything a leader does is correct and does not need to be questioned or disputed. In organizations with high power distance cultures, subordinates generally have a tendency to just agree with every decision from the leader and let their leaders ignore their opinions.

The fifth indicator is the level of the delegation of important jobs. This indicator measures the extent to which a leader is willing to delegate jobs that are considered essential for the survival of the organization. In organizations with a high power distance culture, a leader realizes that he is the main actor of the organization, so that the survival of the organization is fully perceived as his burden. In organizations with low power distance cultures, a leader realizes that he and his subordinates have an equal role in the organization. Therefore, the leader is willing to delegate important tasks to his subordinates and put himself as a supervisor or advisor.

The analysis is done through a descriptive quantitative method measuring the level of power distance among lecturers in Banjarmasin and with confirmatory factor analysis (CFA) to understand which indicators that have the strongest influence in creating power distance culture among lecturers in Banjarmasin. 


\section{Results}

The result of testing the instrument's validity and reliability shows that one indicator is not valid, that is the attitude of subordinates to their superior decisions. This statement is considered confusing by the respondents. Based on the results of the confirmatory factor analysis, they are more inclined to factors other than power distance. Therefore, this indicator is no longer used in this study.

Table 1. Loading Factor and Average Score of Power Distance Variable

\begin{tabular}{|l|l|c|c|}
\hline No & \multicolumn{1}{|c|}{ Indicators } & Loading Factor & Average Scores \\
\hline 1. & Subordinates exclusion in decision-Making & $(0.834)$ & 2.74 \\
\hline 2. & The level of authority used by the leader & $(0.733)$ & 2.44 \\
\hline 3. & $\begin{array}{l}\text { Leader does not open to suggestions and } \\
\text { opinions }\end{array}$ & $(0.812)$ & 2.78 \\
\hline 4. & $\begin{array}{l}\text { Leader's level of reluctance to delegate } \\
\text { important work }\end{array}$ & $(0.682)$ & 2.93 \\
\hline & Average & & 2.72 \\
\hline
\end{tabular}

Table 1 shows that the average value of power distance variable is only 2.72 . This condition means that the power distance among lecturers in the city of Banjarmasin is between medium (3) and low (2). These findings indicate that most of the lecturers at private colleges in Banjarmasin are difficult to accept the imbalance distribution of power between leaders and subordinates. At the current state of the low power distance, lecturers felt that they were needed by the leader, just as they needed the leader. The indicator with the lowest score is the level of the usage of authority used by leaders, which means that it is rare for college leaders in Banjarmasin to use their positions to suppress the lecturers. Considering that most of the lecturers who work in the colleges may also have other jobs, they usually come to the colleges only if they have a class or any other business in the college which makes the interaction between the lecturers and college leaders tend to be low. Lecturers are considered the chairman of the college as colleagues rather than leaders, since the chairman of the college also has a responsibility to teach in the classes, just like other lecturers.

In Table 2, we can see that the indicator with the highest loading factor is Subordinates Exclusion in Decision-Making. This finding indicates that the low power distance is determined by other four indicators, but respondents in this study consider that the most important factor is being involved in making a decision. According to the subordinates, the more they are involved in making important decisions in the organization, the more they feel that there is no power distance in the organization. This indicator also has a low score, meaning that the leaders often involve their subordinates in making important decisions. The connection between the high value of subordinates exclusion in decision-making loading factor with its low average score becomes the main explanation why there is a low power distance culture among lecturers of private colleges in the city of Banjarmasin.

\section{Discussion}

The results of this research show that the power distance culture scores at only 2.72 , still below the average value of 3. This means that there is a low power distance among college lecturers in the city of Banjarmasin. These results are totally different from the data on Hofstede's website (http://geerthofstede.com/indonesia.html) which states that Indonesia has a high power distance values, with a score of 78. The findings of this present study support Jones (2007), which states that culture should be measured within the scope of a group or groups of people, not the State. This research also supports the opinion from McSweeney (2000) claiming that cultures should not be measured nationally because nowadays, easy access to global information is causing the culture no longer confined by national boundaries. 
The low power distance culture among college lecturers in the city of Banjarmasin is especially shown by how leaders are not using their superiority to suppress their subordinates. This condition occurs because lecturers feel that there is no difference in social status between them and the chairman.

It is difficult for chairman in a college to put himself higher than other lecturers because most of the important policies in private colleges are made by the chairman of the foundation, not the chairman of the college. Most of the college officials also realized that if the chairman of the foundation does not extend his term, they will go back into a regular lecturer. This awareness will certainly bring prudence to college chairmen and all of the college officials in how they treat their fellow lecturers.

\section{Conclusion}

There is a low power distance among college lecturers in the city of Banjarmasin, which means that this result is against Hofstede's claim that Indonesia has a high power distance culture. Power distance culture is primarily determined by the level of subordinates involved in making important decisions. Further, researchers can develop this research to a larger number of samples and a bigger scope to increase its generalizability. They can also measure Hofstede's other national cultures to find out their consistency if measured on a smaller scope.

\section{References}

Adair, W., Okumura, T., \& Brett, J. (2001). Negotiation behavior when cultures collide: the united States and Japan. Journal of Applied Psychology, 86, 371-385

Aldhuwaihi, A. (2013). The Influence Of Organisational Culture On Job Satisfaction, Organisational Commitment And Turnover Intention: A Study On The Banking Sector In The Kingdom Of Saudi Arabia. Doctoral, Victoria University, Melbourne.

Dorfman, P. W., \& Howell, J. P. (1988). Dimenstions of National Culture and Effective Leadership patterns: Hoftstede Revisited. Advances in International Comparative Management, 3, 125-150.

Hellrieger, D., \& John W Slocum, J. (2009). Organizational Behavior. Mason: South-Western Cengange Learning.

Jones, M. (2007). Hofstede Culturally Questionable? Paper presented at the Oxford Business \& Economics Conference, UK.

Khatri, N. (2009). Consequences of Power Distance Orientation in Organizations. VISION-The Journal of Business Perspective, 13(1), 1-9.

Kwon, J.-W. (2012). Does China have more than one culture ? Asian Pacific Management Journal, 22(1), 79-102.

McShane, S. L., \& Glinow, M. A. V. (2008). Organizational Behavior : Emerging Realities for The Workplace Revolution. New York: McGraw Hill Irwin.

McSweeney, B. (2000). The Fallacy of National Culture Identification. Paper presented at the 6th Interdisciplinary Perspectives on Accounting Conference, Manchester, UK.

Nasif, E. G., Al-Daeaj, H., Ebrahimi, B., \& Thibodeaux, M. S. (1991). Methodological Problems in Cross-Cultural Research: An Update. Management International Review, 31(1), 79.

Piller, I. (2011). Intercultural Communication: A Critical Introduction. Edinburgh University Press: Edinburgh.

Robertson, C., \& Hoffman, J. (2000). How different are we? An investigation of confucian values in the United States. Journal of Managerial Issues, 12, 34-47.

Wang, K. Y., \& Nayir, D. Z. (2010). Procedural justice, participation and power distance : Information sharing in Chinese firms. Management Research Review, 33(1), 66-78.

Wu, M. Y. (2006). Hoftstede's Cultural Dimenstion 30 Years Later : A Study of Taiwan and the United States. Intercultural Communication Studies, 15(1), 33-42 